\title{
Studies at the Faculty of Medicine of the Stefan Batory University in Vilnius 1919-1939
}

\section{Studia na Wydziale Lekarskim Uniwersytetu Stefana Batorego w Wilnie w latach 1919-1939}

\author{
Małgorzata Przeniosto \\ Department of Pedagogy and Arts, Institute of School Education, Jan Kochanowski University, Kielce, Poland \\ Head of the Department: Prof. Marek Kątny PhD
}

Key words: history of medicine, medical studies, universities in the Second Republic of Poland.

Słowa kluczowe: historia medycyny, studia medyczne, uniwersytety w II Rzeczypospolitej.

\begin{abstract}
In the article I aimed to examine the conditions and the organisation of the studies at the Faculty of Medicine at the Stefan Batory University (SBU) in Vilnius. Therefore, it became my interest to analyse the functioning of the Faculty and to determine their academic team. Also, it was crucial to define the general rules of study in the interwar period, examine the course of medical and pharmaceutical studies at the SBU, and determine the level of student commitment. The students of the Faculty of Medicine were among the most 'busy' at the university. Medical studies were by far the most difficult, both due to the complexity and diversity of theoretical and practical classes, as well as the large number of exams. The studies lasted 16 trimesters, the number of subjects ending in an exam was the highest -20 , and there were 5 subjects which ended in a test.
\end{abstract}

\section{Streszczenie}

Celem artykułu było zbadanie warunków i organizacji studiów na Wydziale Lekarskim Uniwersytetu Stefana Batorego (USB) w Wilnie. Interesujące było przeanalizowanie funkcjonowania Wydziału, ustalenie jego kadry, określenie ogólnych zasad studiowania w okresie międzywojennym, zbadanie przebiegu studiów lekarskich i farmaceutycznych na USB oraz ustalenie stosunku studentów do zajęć. Wydział Lekarski należał do największych wydziałów na uniwersytecie pod względem liczby pracowników naukowo-dydaktycznych oraz osób studiujących. Przykładowo na początku lat 30. ubiegłego wieku miał ok. 850 studentów (ogólna liczba studiujących na USB wynosiła ok. 3500). W tym czasie Wydział zatrudniał 23 profesorów, miał 14 katedr zwyczajnych i 9 nadzwyczajnych. Studenci Wydziału Lekarskiego należeli do najbardziej „zapracowanych” na uczelni, studia medyczne były bowiem zdecydowanie najtrudniejsze, zarówno ze względu na skomplikowanie i różnorodność zajęć teoretycznych oraz praktycznych, jak i dużą liczbę egzaminów. Studia trwały 16 trymestrów, wprowadzono najwięcej przedmiotów egzaminacyjnych - 20, a ponadto 5 , z których przewidziano kolokwia.

\section{Introduction}

In interwar Poland, medicine was taught at the five then-existing state universities: The University of Warsaw (UW), Jagiellonian University (JU), Jan Kazimierz University in Lvov (JKU), Poznan University (PU), and the Stefan Batory University in Vilnius (SBU), each of which had a medical department. In Warsaw, there was also the Academy of Dentistry.

In order to closely examine the studies at the Faculty of Medicine (FM) at the SBU, I aimed to determine the general conditions of study as well as the organisation of medical studies. Therefore, it became my interest to analyse the functioning of the FM in comparison with the entire University and other faculties of its kind in Poland. A further aim was to analyse the terms of staff employment and the academic team of the FM - professors, associate professors, auxiliary scholars their numbers, teaching duties, and research activity. Also, it was crucial to define the general rules of study in the interwar period, examine the course of medical and pharmaceutical studies at the SBU, and determine the level of student commitment. The issue has not been discussed so far, apart from some information contained in memorial books dedicated to the SBU. This article provides an analysis of a variety of materials from the interwar period, particularly deeds, printed sources issued by the SBU, as well as the archival SBU documents stored in the Lithuanian Central State Archive in Vilnius (LCSA) and the materials available in the largest of the Polish state archives - the Archives of New Records in Warsaw (ANR). 


\section{General information on the Faculty of Medicine}

The efforts to establish (reactivate) a university in Vilnius began in November 1918, and eventually it opened in October 1919. In the interwar period the SBU was the smallest Polish university, both in terms of the number of students $(1919 / 1920-547$ students, $1921 / 1922$ - 1735 students, 1932/1933 - 3923 students ${ }^{1}$ and the number of academic staff. There were six (seven) faculties: Humanities, Medicine, Mathematics and Natural Sciences, Law and Social Sciences, Agriculture (since 1938), and Fine Arts and Theology. Throughout the interwar period Pharmaceutical Study (PhS) was also established as a branch of the Faculty of Medicine (FM). Similar structures were also present at other universities; only at the UW was the PhS transformed into the Faculty of Pharmacy in 1926.

The FM was one of the largest of the SBU, both in terms of the number of research-teaching staff and the number of students. After the period of organisation (1919-1922), the FM became the largest faculty in terms of the number of professors - over 20 of them were employed in the late twenties. Since the early thirties only the Faculty of Mathematics and Natural Sciences was comparable to or slightly larger than the FM. In the academic year 1923/1924 there were 675 students (of the total 2209 students at the SBU), in 1930/1931 - 853 (of 3618), and in 1937/1938 - 832 (of 3148$)^{2}$. At other universities, the number of students of medical faculties varied and was not always proportional to the size of the university. When it comes to medicine, the largest was the UW while the UP, although half the size, held the second position. In some years, the total number of students of medicine and pharmacy at the UP exceeded the UW. In the academic year 1934/1935 there were 1426 students at the UW and 1572 at the UP; at that time there were 871 students at JU (at both faculties), 901 at the JKU in Lviv, and 814 at the FM of the SBU. The FM of Vilnius University was thus comparable to the JU and the JKU, despite the fact that the latter universities had twice as many students in all faculties [1].

In the beginning the SBU faced with major staffing problems, particularly concerning professors. Some of the professorial chairs awarded to the University ${ }^{3}$ remained vacant. Sometimes it was a temporary situation while the right candidates were being sought, often however, deputy professors were hired for a longer period or the chairs remained vacant and classes were entrusted to professors who headed other cathedrals. At the FM the chairs were taken very quickly. For example, in the academic years 1931/1932 and 1932/1933 the FM had 14 full chairs (Pathological Anatomy, Bacteriology and Serology, Physiological Chemistry, Surgery, Internal Medicine (two chairs), Pharmacology, Physiology, Hygiene, Neurology, Ophthalmology, Otolaryngology, Obstetrics and Gynecology, and Psychiatry) and nine associate chairs (Descriptive Anatomy, Biology, Dermatology and Venereology, Pharmacy and Pharmaceutical Chemistry, Pharmacognosy and Cultivation of Medical Plants, Histology and Embryology, Forensic Medicine, General Pathology, and Paediatrics). All of them were occupied, and two associate professors temporarily guided full professorial chairs. For comparison, the FM at the UW had 23 chairs and employed 20 professors at the time [2].

The SBU developed its internal organisational structure in accordance with the statutory regulations, thus its faculties were divided into institutes. A professor was the head of a particular chair, entrusted by the Ministry of Religious Denominations and Public Education (MRDPE), and was in charge of a respective institute. Since the institutes were mostly responsible for the organisation of teaching, they were assigned to specific classes. Therefore, the professors of the FM who were responsible for clinical classes headed clinics instead of institutes. Also, specific premises were assigned to particular institutes for both staff needs and teaching purposes. Some of them were housed in the university buildings, others outside. Those were mainly the clinics, which not only were the counterparts of institutes, but also were actual clinics with hospital beds, located in actual hospitals, mostly in the Military Hospital in Antakalnis. The only property of the SBU was the premises in the Clinic of Gynaecology and Assisted Birth. It was located in Boguslawska Street in a former infirmary that the University purchased in the early twenties and renovated from scratch [3-5].

Students of both sexes were accepted to study at the FM, both in medical and pharmaceutical studies. Women were accepted into the Faculty from the first year of its existence. Depending on the year, women constituted $20 \%$ to $35 \%$ of students of medicine and from $10 \%$, in the initial period, up to $75 \%$ students of pharmacy in the thirties ${ }^{4}$. Most students of the FM were declared Roman Catholics. For example, in the academic year 1925/1926 there were 312 people, with 147 declaring the religion of Moses, 30 - Orthodox, 3 - Protestant, and 2 - Islamic [6].

\section{Research and teaching staff of the Faculty}

In the interwar period, the FM employed a total of 39 professors as heads of chairs (see Table 1), the vast

\footnotetext{
In the academic year 1921/1922, at the University of Warsaw, the largest university at the time, there were 7518 students; in $1932 / 1933$ there were 9933 students.

${ }^{2}$ In terms of the number of students (full students and auditors) the FM was usually the second largest of the SBU. In some years (including the $\mathrm{PhS}$ ) it was the largest.

${ }^{3}$ In the interwar period, the system of hiring professors at Polish universities was based on a limited number of associate and full (the most prestigious) professorial chairs awarded by the state authorities. Professors were employed as heads of departments. They were appointed by the state authorities at the request of the Faculty Council.

${ }^{4}$ In the thirties, they comprised from $30 \%$ to $40 \%$ of the SBU students.
} 
Table 1. Professors employed at the FM of the SBU in the years 1919-1939

\begin{tabular}{|c|c|c|c|}
\hline \multirow[t]{2}{*}{ Full name } & \multirow[t]{2}{*}{ Specialization (chair’s profile) } & \multicolumn{2}{|c|}{ Employed as } \\
\hline & & $\begin{array}{l}\text { Associate } \\
\text { Professor }\end{array}$ & $\begin{array}{c}\text { Full } \\
\text { Professor }\end{array}$ \\
\hline Abramowicz Ignacy & Ophthalmology & 1937-1939 & \\
\hline Alexandrowicz Jerzy Stanisław & Histology & $1921-1929^{a}$ & \\
\hline Bujak Władysław & Paediatrics & 1937-1939 & \\
\hline Burdziński Tadeusz & Obstetrics and gynaecology & & $1922-1925^{b}$ \\
\hline Eiger Marian & Physiology & & $1922-1938^{c}$ \\
\hline Godlewski Emil & Biology & & $1919 / 1920^{d}$ \\
\hline Gryglewicz Teofil & Bacteriology and serology & & $1921-1936^{b}$ \\
\hline Hiller Stanisław & Histology and embryology & 1929-1938 & 1938-1939 \\
\hline Jakowicki Władysław & Obstetrics and gynaecology & $1925-1933$ & 1933-1939 \\
\hline Januszkiewicz Aleksander & Internal diseases & & 1921-1939 \\
\hline Jasiński Wacław & Paediatrics & 1922-1933 & $1933-1936^{b}$ \\
\hline Karaffa-Korbut Kazimierz & Hygiene & & $1922-1935^{b}$ \\
\hline Karaffa-Korbut Władysław & Pharmacy and pharmaceutical chemistry & 1923-1939 & \\
\hline Legeżyński Stanisław & Bacteriology & 1937-1939 & \\
\hline Leyko Emil & Pharmacology & 1937-1939 & \\
\hline Malinowski Feliks & Dermatology and venereology & 1929-1934 & \\
\hline Michejda Kornel & Surgery & $1922-1931$ & 1931-1939 \\
\hline Mikulski Antoni & Psychiatry & & $1923-1925^{b}$ \\
\hline Mozołowski Włodzimierz & Physiological chemistry & 1935-1939 & \\
\hline Muszyński Jan Kazimierz & Pharmacognosy and cultivation of medical plants & 1923-1937 & 1937-1939 \\
\hline Nowakowski Brunon & Hygiene & 1937-1939 & \\
\hline Opoczyński Kazimierz & Pathological anatomy & $1921-1930$ & $1930-1938^{c}$ \\
\hline Orłowski Zenon & Internal diseases & & $1922-1933^{e}$ \\
\hline Pawlas Tadeusz & Dermatology and venereology & 1935-1939 & \\
\hline Pelczar Kazimierz & General pathology & 1930-1939 & \\
\hline Reicher Michał & Descriptive anatomy & 1922-1934 & 1934-1939 \\
\hline Retinger Juliusz & Physiological chemistry & & $1921-1928$ \\
\hline Rose Maksymilian & Psychiatry & 1931-1934 & $1934-1937^{b}$ \\
\hline Ruebenbauer Henryk & Applied pharmaceuticals & 1937-1939 & \\
\hline Schilling-Siengalewicz Sergiusz & Forensic medicine & 1924-1935 & 1935-1939 \\
\hline Seńkowski Michał & Physiological chemistry & & $1929-1934^{c}$ \\
\hline Szmurło Jan & Otolaryngology & & $1923-1936^{c}$ \\
\hline Szymański Julian & Ophthalmology & & $1922-1935^{c}$ \\
\hline Traczewski Cezar Szczęsny & Pharmacology & & $1921-1935^{c}$ \\
\hline Trzebiński Stanisław & History of philosophy and medicine & & $1922-1930^{b}$ \\
\hline Wąsowski Tadeusz & Otolaryngology & $1936-1937^{b}$ & \\
\hline Wilczyński Jan Zygmunt & Biology & $1925-1933^{\mathrm{e}}$ & \\
\hline Władyczko Stanisław & Neurology & $1919 / 1920$ & $1920-1933^{e}$ \\
\hline Ziemacki Józef Kazimierz & General and topographic surgery & $1919 / 1920$ & $1920-1925^{b}$ \\
\hline
\end{tabular}

aMoved to JKU; ${ }^{b} d i e d ;$ cretired; ${ }^{a}$ moved back to JU; eleft his chair due to the new Act on Academic Schools; retired since 1934. Source: [2, 5-12]. 
majority of whom were physicians, with a few representatives of other disciplines - pharmacy, chemistry, biology, anthropology [2, 5-12].

Specific names of chairs occupied by professors changed. Sometimes a professor was entrusted a different, free chair, as it was more in line with the mainstream of his scientific interests. For example, the chair of Aleksander Januszkiewicz was initially called General Diagnosis and Internal Treatment, from 1922 - Detailed Pathology and Internal Treatment, and from 1934 - Internal Medicine. The MRDPE listed it as Internal Diseases. The naming in Table 1 was adopted from the nomenclature used by the Ministry [2, 11]. The SBU also hired titular professors. They were professors without a chair, who only had the right to be referred to as 'Professor' while their earnings remained without change. A titular professor worked as an associate or senior assistant.

Throughout the interwar period 70 associate professors were employed at the SBU; they were scholars after habilitation (professorial thesis), and 19 of them later received chairs at the university. Due to the nature of the then habilitation, which only gave the right to lecture ${ }^{5}$, only those who were officially allowed to teach applied for that title. Hence the number of habilitations was small. In the initial period (1919-1923), the University did not hire associates at all, or only one person was employed. By the end of the twenties there were no more than four of them. In the thirties, the number increased (the most in comparison with other faculties), in some years up to 11 . The vast majority of associates were men. The SBU employed five women who received habilitation, including three at the FM. Their number was low in general, as well as the number of women-professors. The list of assistants from 1937 (which did not include those who received chairs) included only 34 women of the 551 total in the whole country [13-15].

Other research and teaching staff were counted as auxiliary scientific force. Their employment, as well as professors, was limited by the MRDPE. In the academic year 1922/1923, 143 such posts were secured for the SBU ( 89 for the FM). Part of them was not yet occupied, and the FM employed 61 auxiliary scholars. They were mostly younger assistants and deputy assistants, 22 senior assistants, and only five lecturers and equivalent positions (e.g. prosectors) [16]. In the year 1931/1932, the SBU had 158 auxiliary posts, including 18 lecturers and equivalent positions (the FM - 12), and 72 senior assistants (the FM - 40), and almost all of them were occupied [2].

Most of the professors were active researchers. Those better known in the scientific world were Professors Kazimierz Karaffa-Korbutt, Kazimierz Pelczar, and Maksymilian Rose. The former dealt with research in the field of bacteriology, epidemiology, and hygiene and was known for his works on the treatment of infectious diseases and hygiene. Kazimierz Pelczar was famous for his studies on resistance in malignant tumours. Maximilian Rose dealt mainly with the cytoarchitecture of the brain [17-20]. Speaking of famous people, it is worth mentioning those who were recognised for more than their scientific work. Among them was ophthalmologist Julian Szymanski, a senator in the years 1928-1930 and Speaker of the Senate. Another such person was Aleksander Januszkiewicz, personal physician of Jozef Pilsudski $[21,22]$.

Teaching was an important aspect of the university work. The time spent by scholars conducting classes varied greatly. The nomination act obligated a professor to at least $5 \mathrm{~h}$ of lectures and $2 \mathrm{~h}$ of classes. Universities usually accepted those numbers or slightly higher. They also had the right to change the proportions of the two forms, converting $1 \mathrm{~h}$ of lecture into $2 \mathrm{~h}$ of classes or seminars. Professors were also allowed to conduct overtime classes; however, they would not receive a salary unless the class was approved by the MRDPE [23]. For assistant professors the number of teaching hours depended on their terms of employment. Since habilitation only gave the right to lecture, associate professors could take full-time jobs as deputy professors (number of working hours that of a professor), assistant professors (also prosectors at the FM), or senior assistants, or only conduct commissioned classes. As for the auxiliary scientific force, their working week was $30 \mathrm{~h}$. The weekly schedule depended on the custom at a particular faculty. At the FM professors and deputy professors lectured at least half of the days of the week (Monday to Saturday), and auxiliary scholars worked for a few hours every day.

\section{Teaching at the Faculty of Medicine}

According to the then regulations (Act of 1920) the academic year consisted of at least 180 days of lectures plus the time devoted to exams. There were three trimesters (10 weeks each). The candidates were accepted both as students and auditors. To become a university student one had to provide a certificate of secondary education received in one of the state comprehensive secondary schools. As for other schools, the certificate had to be recognised by the MRDPE as equivalent with a certificate of secondary education [24]. Students were entitled to sign up for lectures at the faculty of their choice, attend lectures at other faculties, take examinations, apply for degrees: lower,

${ }^{5}$ The procedure was carried out at the faculty level (and had to be approved by the MRDPE) on the basis of just one work - the dissertation. Other achievements were not required, although they could be taken into account by the reviewers. 
at the end of study 6 , and higher, of a doctor (auditors were not entitled to the two latter ${ }^{7}$ ), and establish academic associations. Also, students were obliged to take the oath, pay the registration fee and other related fees in the following years, observe the academic laws, and care for academic dignity [24]. The Act of 1933 introduced minor changes. Classes, seminars, and lectures were now obligatory for students. Also, regular students, auditors, and doctoral students were all counted as legitimate students of the Stefan Batory University [25].

The regulations issued by the MRDPE introduced compulsory subjects (universities often called them courses) in which students had to take examinations and tests (those basic for a particular discipline). Also, optional subjects were introduced, specified in the regulations or according to the decision of the Faculty Council. Some more significant differences between various disciplines concerned the exams introduced by the said regulations. The approach remained fairly liberal at the Faculties of Philosophy, Humanities, Mathematics, and Natural Sciences [26]. Faculties of Medicine and Law were stricter for their students and Faculties of Medicine generally had the highest requirements. The studies lasted 16 trimesters, the number of subjects ending in an exam was the highest 20 , and there were five subjects which ended in a test (see Table 2). Apart from regular classes and seminars, clinical classes and internships were also obligatory (these forms of study required the student to obtain credit) [27].

Examinations at the FM were taken before departmental boards. A student could be given four grades: unsatisfactory, satisfactory, good, and excellent. If they failed (first and second attempt) the compulsory exams after the first 3 years, they had to do the year

Table 2. The curriculum for medical studies recommended ${ }^{8}$ by the Ministry of Religious Denominations and Public Education in the regulation of 1920

\begin{tabular}{|c|c|c|c|c|c|c|}
\hline \multirow{2}{*}{$\begin{array}{l}\text { Year } \\
\text { of study }\end{array}$} & \multirow[t]{2}{*}{ Subject } & \multicolumn{4}{|c|}{ Number of hours ${ }^{a}$} & \multirow{2}{*}{$\begin{array}{l}\text { Form of completion } \\
\text { in a given year }\end{array}$} \\
\hline & & L & C & $\mathrm{CC}$ & 1 & \\
\hline \multirow[t]{6}{*}{ I } & Chemistry & 130 & 210 & - & - & $E$ \\
\hline & Physics & 110 & 40 & - & - & $\mathrm{E}$ \\
\hline & Correct anatomy & 110 & 160 & - & - & C \\
\hline & Correct histology & 30 & 40 & - & - & C \\
\hline & Logic for medics & 10 & - & - & - & ADD \\
\hline & Medical propedeutics & 20 & - & - & - & COMP \\
\hline \multirow[t]{8}{*}{ II } & Correct anatomy & 50 & 220 & - & - & E \\
\hline & Biology & 80 & - & - & - & E \\
\hline & Physiological chemistry & 60 & 120 & - & - & E \\
\hline & Physiology & 150 & 40 & - & - & $E$ \\
\hline & Correct histology & 40 & 60 & - & - & $E$ \\
\hline & Anthropology & 20 & - & - & - & $T$ \\
\hline & Anatomy of the central nervous system & - & 20 & - & - & C \\
\hline & Embryology & 50 & - & - & - & COMP \\
\hline \multirow[t]{5}{*}{ III } & Bacteriology & 60 & 50 & - & - & E \\
\hline & Pharmacology & 60 & - & - & - & E \\
\hline & General and experimental pathology & 100 & - & - & - & $\mathrm{E}^{\mathrm{c}}$ \\
\hline & Psychology & 20 & - & - & - & $\mathrm{T}$ \\
\hline & Pathological anatomy & 120 & 60 & - & - & C \\
\hline
\end{tabular}

\footnotetext{
${ }^{6}$ The act did not specify its name. In the following years, depending on the discipline, different degree names were introduced: Master's degree (also Master of Pharmacy), Doctor's, Engineer's, Artist's.

'If an auditor became a full student, the classes they had already attended could be included in the course of their studies.

${ }^{8}$ Faculty Councils could increase the proposed number of hours devoted to each subject. Also, they had the right to freely distribute them between different trimesters; however, it was recommended that the amount of hours in the third trimester be reduced so that the students would have enough time to prepare for exams. The Ministry provided an example of such a division.
} 
Table 2. Cont.

\begin{tabular}{|c|c|c|c|c|c|c|}
\hline \multirow{2}{*}{$\begin{array}{l}\text { Year } \\
\text { of study }\end{array}$} & \multirow[t]{2}{*}{ Subject } & \multicolumn{4}{|c|}{ Number of hours ${ }^{a}$} & \multirow{2}{*}{$\begin{array}{l}\text { Form of completion } \\
\text { in a given yearb }\end{array}$} \\
\hline & & $\mathrm{L}$ & $\mathrm{C}$ & $\mathrm{CC}$ & 1 & \\
\hline & Topographic anatomy & 40 & 30 & - & - & C \\
\hline & Pathological histology & - & 70 & - & - & C \\
\hline & Surgery & 30 & - & - & - & COMP \\
\hline & Pharmacognosy & 20 & - & - & - & ADD \\
\hline & Internal diseases & - & - & - & 40 & C \\
\hline & Propedeutics & - & - & 100 & - & C \\
\hline \multirow[t]{8}{*}{ IV } & Pathological anatomy & 60 & 40 & - & - & $C$ \\
\hline & General treatment & 20 & - & - & - & ADD \\
\hline & Surgery & - & - & 200 & 60 & C \\
\hline & Internal diseases & - & - & 150 & 60 & C \\
\hline & Dermatology and syphilidology & - & - & 130 & - & C; (E after $\left.6^{\text {th }} y.\right)$ \\
\hline & Neurology & - & - & 80 & - & $C ;\left(\text { E after } 6^{\text {th }} y .\right)^{d}$ \\
\hline & Paediatrics & - & - & 120 & - & C; (E after $\left.6^{\text {th }} \mathrm{y}.\right)$ \\
\hline & Obstetrics and gynaecology & - & - & 200 & $3 w_{.}^{e}$ & $C$ \\
\hline \multirow[t]{13}{*}{$V^{f}$} & Pathological anatomy - diagnosis & 30 & - & - & - & $E^{g}$ \\
\hline & Hygiene & 40 & 20 & - & - & $\mathrm{E}$ \\
\hline & Forensic medicine & 70 & 30 & - & - & $\mathrm{E}$ \\
\hline & Dentistry & 40 & - & - & - & COMP \\
\hline & History of medicine & 20 & - & - & - & COMP \\
\hline & Social hygiene & 30 & - & - & - & ADD \\
\hline & Laryngology of rhinology & - & - & 40 & - & $\mathrm{T}$ \\
\hline & Otology & - & - & 30 & - & $\mathrm{T}$ \\
\hline & Surgery & - & - & 150 & 90 & $\mathrm{C}$ \\
\hline & Internal diseases & - & - & 150 & 110 & C \\
\hline & Ophthalmology & - & - & 50 & - & C \\
\hline & Obstetrics and gynaecology & - & - & 80 & - & $C ;\left(E\right.$ after $\left.6^{\text {th }} y.\right)$ \\
\hline & Psychiatry & - & - & 90 & - & $C ;\left(E \text { after } 6^{\text {th }} y .\right)^{d}$ \\
\hline \multirow[t]{7}{*}{$\mathrm{VI}$} & History of medicine & 20 & $20^{h}$ & - & - & C \\
\hline & Orthopaedics & 30 & - & - & - & ADD \\
\hline & Medical ethics & 10 & - & - & - & ADD \\
\hline & Surgery & - & - & 50 & 60 & $\mathrm{E}$ \\
\hline & Internal diseases & - & - & 50 & - & $\mathrm{E}$ \\
\hline & Ophthalmology & - & - & 60 & - & $\mathrm{E}$ \\
\hline & Dentistry & - & - & 40 & - & $\mathrm{T}$ \\
\hline
\end{tabular}

${ }^{a}$ Abbreviated as follows: $L$ - lectures, $C$ - classes, CC - clinical classes, I - internship; ${ }^{b}$ abbreviated as follows: $E$ - examination, $T$ - test, $C$-credit, COMP - compulsory subject, credited in the following years; $A D D$ - additional subject; the examination could also be taken after the fourth year; ${ }^{d}$ one examination was scheduled in Psychiatry and Neurology; ${ }^{e}$ continuous internship during the summer holiday after the fourth or fifth year -3 weeks; the exams required after the fifth year could also be taken at a later date; ${ }^{a}$ an examination in Pathological Anatomy combined with Pathological Histology; 'hey were called 'seminars', but in fact they were classes. Source: [27]. 
again (this was allowed no more than twice). The examinations and tests after the fifth and sixth years of study (those after the sixth year were clinical exams) could be retaken twice with the approval of the examination board, and the third time with the approval of the Faculty Council and the MRDPE. To pass them all, three additional years were given after the completion of the $16^{\text {th }}$ trimester of study, and the extension of this deadline was only possible with the consent of the Ministry. The degree of Doctor was awarded after passing all the exams and tests, without writing a thesis [27].

The regulations of 1928 regarding medical studies introduced the obligation to attend lectures. However, students were given the right to take more exams than previously after approval; three years were given to complete that, and with the consent of the Faculty Council this period could be lengthened [28].

As mentioned, there were also Pharmaceutical Studies run at the FM. Its auditors were counted among the students of the Faculty. Pharmaceutical Study were initially planned for 3 years, since the academic year 1933/1934 for 11 trimesters, and the rigorous approach typical of the whole Faculty was applied. Graduates were given a Master's degree in Pharmacy $[1,5,29]$. In the first year of Pharmacy students attended the following classes: General Chemistry, Inorganic Chemistry, Analytical Qualitative Chemistry, Physics, Experimental Physics, Molecular Physics, General Botany and Morphology, Plant Anatomy and Systematics, Crystallography, Zoology and Parasitology, and Mineralogy and Geology. In the second year there were: Analytical Quantitative Chemistry, Organic Chemistry, Physiological Chemistry, Physical Chemistry, Hygiene, Pharmacognosy, Microbiology, and First Aid in an Emergency. In the third year: Pharmaceutical Chemistry, Technical Chemistry, Bacteriology, Analysis of Powder Materials, Applied Pharmaceuticals, Pharmacognosy and Cultivation of Medical Plants, Microscopic Analysis and Forensic Chemistry, and History of Pharmacy [30].

In the interwar period, an important element of the student assessment was their promptness in completing subsequent years of study and the university in general ${ }^{9}$. Depending on the faculty, the situation varied in this respect. Generally, students enjoyed a lot of freedom with regard to attending classes, taking exams, and the writing their Master's thesis, which did not contribute to a timely graduation. The period of study was not ultimately defined and the number of trimesters was only a suggestion from the MRDPE or the University. Students often used the opportunity to re-enrol in the same year of study (which was permitted without limitation). In most cases they wanted to take a break from studying, or did not feel strong enough to take the examinations. The timeliest were students of Law, Pharmacy, Theology, and Medicine [1, 31, 32], although even in these disciplines it applied to less than half of the total. For example, in the academic year 1933/1934 a Master's degree in Pharmacy was received by $42 \%$ of the students, Law - 38\%, Theology - 25\%, and Medicine $23 \%$. In Fine Arts it was 21\%, Humanities - 13\%, Agriculture $-8 \%$, and Mathematics and Natural Sciences only $6 \%$ [1].

The situation was similar at other universities, although in comparison with even the largest of them, the SBU performed better in terms of graduating on time. This was also the case in Medicine and Pharmacy. The reasons for the delay varied. For instance, at the UW students indicated the necessity of earning a living ${ }^{10}$, poor quality of secondary education, and the need to make up for the backlog [35].

\section{Conclusions}

The students of the Faculty of Medicine were among the most "busy" at the university. Medical studies were by far the most difficult, both due to the complexity and diversity of theoretical and practical classes, as well as the large number of exams. Nevertheless, they engaged in the university life, e.g. by joining student associations. On the other hand, when looking at the entire University, diligence was not their strongest point. Less than half of the students graduated on time; however, the students of the FM performed better than others in this respect. The lecturers employed at the FM took their scientific work and teaching very seriously and spent a fair amount of time performing their duties at the university. At the FM teaching was scheduled for at least half the days of the week.

\section{Conflict of interest}

The author declares no conflict of interest.

\footnotetext{
${ }^{9}$ The authorities of the FM often had to solve problems that arose from the complexity of medical studies. Groups of students who failed their exams often submitted petitions requesting additional exam dates or extension of the examination session. They wrote both to the University authorities and the MRDPE.

${ }^{10}$ The cost of study was quite substantial. Students had to make a living and pay tuition fees. In addition to the annual registration fee, also individual examinations, tests, the choice of topic for the master's thesis, and its review were all payable. State scholarships were not sufficient, e.g. in the year 1936/1937 the students of state universities were awarded 2339 scholarships (out of 5304 requested). Only 102 students received full scholarships, 1469 people got 50\%, and 768 were awarded 25\%. A full scholarship at that time was about 120 PLN per month. State funds were also a source of long-term loans to cover the cost of studies (in that year 4395 such loans were granted out of 8428 applications) [33]. Five hundred 545 of the SBU students received either form of financial assistance. The University also sought to support indigent students by postponing the payment of, usually, half of tuition fees. In the analysed year, such assistance was granted to 568 people [34].
} 


\section{References}

1. Wittlinowa H. Atlas szkolnictwa wyższego. MRDPE, Warsaw 1937.

2. ANR, MRDPE, sygn. 241.

3. LCSA, SBU, ap. 3 IXB, b. 190.

4. University staff in the academic year $1933 / 1934$ and the changes in the years 1929/1930, 1930/1931, 1931/1932, 1932/1933. SBU, Vilnius 1934.

5. Trzebiński S. Wydział Lekarski SBU w latach 1919-1929. In: Księga pamiątkowa ku uczczeniu CCCL rocznicy założenia i X wskrzeszenia Uniwersytetu Wileńskiego. Dziesięciolecie 1919-1929. USB, Vilnius 1931; 2: 377-507.

6. LCSA, SBU, ap. 3 IXB, b. 85.

7. LCSA, SBU, ap. $1 \mathrm{IBb}$, b. 147

8. LCSA, SBU, ap. $1 \mathrm{IBb}$, b. 635.

9. LCSA, SBU, ap. $1 \mathrm{IBb}$, b. 722

10. LCSA, SBU, ap. $1 \mathrm{IBb}$, b. 726 .

11. LCSA, SBU, ap. $1 \mathrm{IBb}$, b. 729 .

12. University staff and lists of lectures 1919/1920-1938/1939. SBU, Vilnius 1919-1939.

13. List of associate professors dated 31st December, 1937. MRDPE, Warsaw 1938.

14. University staff in the academic year 1936/1937. USB, Vilnius 1937.

15. University staff in the academic year 1938/1939. USB, Vilnius 1939.

16. List of lectures and university staff in the academic year 1922/1923. SBU, Vilnius 1922.

17. Ginko T. Zarys dziejów Wydziału Lekarskiego Uniwersytetu Stefana Batorego. In: Z dziejów Almae Matris Vilnensis. Księga pamiątkowa ku czci 400-lecia założenia i 75-lecia wskrzeszenia Uniwersytetu Wileńskiego. Piechnik L, Puchowski K (eds.). WAM, Krakow 1996; 185-201.

18. Śródka A. Uczeni polscy XIX-XX stulecia. Vol. 2. Aries, Warsaw 1995.

19. Śródka A. Uczeni polscy XIX-XX stulecia. Vol. 3. Aries, Warsaw 1997.

20. Samujłło J, Rodziewiczowa J. Karaffa-Korbutt Kazimierz. In: Polski Słownik Biograficzny. Ossolineum, Wroclaw 1968; 14: 40-1.

21. Majchrowski J (ed.). Kto był kim w Drugiej Rzeczypospolitej. BGW, Warsaw 1994.

22. Żongołłowicz B. Dzienniki 1930-1936. Retro-Art, Warsaw 2004.

23. LCSA, SBU, f. 175, ap. 1 IA, b. 955

24. Ustawa z dnia 13 VII 1920 r. o szkołach akademickich (The Act of 13th August, 1920, on Academic Schools). Official Gazette of the Republic of Poland 1920; 72: 1277-94.

25. Ustawa z dnia 15 III 1933 r. o szkołach akademickich (The Act of $15^{\text {th }}$ March, 1933, on Academic Schools). Official Gazette of the Republic of Poland 1933; 29: 594-603.

26. Przeniosło M. Zajęcia dydaktyczne na Uniwersytecie Stefana Batorego w Wilnie w okresie międzywojennym. Przegląd Historyczno-Oświatowy 2014; 57: 87-103.

27. Rozporządzenie Ministra Wyznań Religijnych i Oświecenia Publicznego w sprawie organizacji studiów lekarskich w uniwersytetach państwowych (Regulation of the Minister of Religious Denominations and Public Education on the Organization of Medical Studies at State Universities). Dziennik Urzędowy MWRiOP (Official Gazette of the MRDPE) 1920; 20: 304-16.

28. Rozporządzenie Ministra Wyznań Religijnych i Oświecenia Publicznego z 16 III 1928 r. w sprawie organizacji studiów lekarskich w uniwersytetach państwowych (Regulation of the Minister of Religious Denominations and Public Education of $16^{\text {th }}$ March, 1928, on the Organization of Medical Studies at State Universities). Dziennik Urzędowy MWRiOP (Official Gazette of the MRDPE) 1928; 8: 318-325.

29. Kronika Uniwersytecka z roku akademickiego 1937/1938. Rocznik Uniwersytetu Stefana Batorego w Wilnie 19381939: 181-203.

30. List of lectures in the academic year 1931/1932. SBU, Vilnius 1931.

31. Mały Rocznik Statystyczny 1930. GUS, Warsaw 1930.

32. Mały Rocznik Statystyczny 1934. GUS, Warsaw 1934.

33. Mały Rocznik Statystyczny 1938. GUS, Warsaw 1938.

34. Kronika Uniwersytecka z roku akademickiego 1936/1937. Rocznik Uniwersytetu Stefana Batorego w Wilnie 19371938: 7-12.

35. Sprawozdanie z działalności Uniwersytetu Warszawskiego za rok akademicki 1928/1929. UW. Warsaw 1929.

\section{Address for correspondence:}

Małgorzata Przeniosło MD, PhD

Department of Pedagogy and Arts

Jan Kochanowski University

ul. Krakowska 11, 25-029 Kielce, Poland

Phone: +48 413496769

E-mail: malgorzata.przenioslo@ujk.edu.pl 